\title{
Improving the Efficacy of the Nigerian Electric Power Transmission Network Using Static Synchronous Compensator (STATCOM)
}

\author{
Aneke N.E* Ngang, N.B \\ Department of Electrical /Electronic Engineering, Enugu State University of Science and Technology, \\ PMB 01660 Enugu, Nigeria
}

\begin{abstract}
This paper deals with the voltage profile enhancement on the Nigerian $330 \mathrm{kV}$ transmission power network using static synchronous compensator (STATCOM). Due to increase in power demand, modern power system networks are being operated under highly stressed conditions. This has resulted to difficulty in meeting reactive power requirement especially under planned or sudden changes in voltages, and hence maintaining the bus voltage within acceptable limits has been a major challenge in the power system network, hence the need for this paper which led to the introduction of Static Synchronous Series Compensator into the Nigeria National Grid (NNG) network for the improvement in electric power transmission. The $330 \mathrm{kV} 58$ bus NNG was modeled in PSAT and implemented in Matlab/Simulink for the compensation of the identified voltage violated buses. Transmission network data obtained from Transmission Company of Nigerian (TCN) Osogbo and was used to model the test network. Result of simulations of the network models reveal that STATCOM reasonably improved the voltage stability of the violated buses in the Nigeria network. The insertion of the STATCOM gave $100 \%$ improvement in voltage stability relative to a network without any device.
\end{abstract}

Keywords: Voltage stability, STATCOM, HVDC, Voltage profile, FACT, MATLAB/SIMULINK, PSAT

DOI: $10.7176 / \mathrm{JIEA} / 11-2-02$

Publication date: April $30^{\text {th }} 2021$

\section{INTRODUCTION}

Due to increase in electricity power demand, modern power system networks are being operated under highly stressed conditions. This has resulted to difficulty in meeting reactive power requirement especially under planned or sudden changes in voltages, and hence maintaining the bus voltage within acceptable limits has been a major hurdle in the power system. Above all, there is an infinite challenges in the voltage regulations along the transmission lines even as the conventional means like : Excitation control and voltage regulators at the generating stations, use of tap changing transformers at sending end and receiving end of the transmission lines, switching in shunt reactors during low loads or while energizing long Extra High Voltage lines(EHV), switching in shunt capacitors during high loads or low power factor loads, use of series capacitors in long EHV transmission lines and distribution lines in case of load fluctuations, use of tap changing transformers in industries, substations, distribution substations for reactive power compensations etc. are used in voltage regulations, there is still voltage rise and voltage drops at power stations. In this paper Static Synchronous Compensator (STATCOM) was introduced into the Nigeria grid network for the enhancement in electric power transmission.

Nigeria power industry is shifting from its feat as the greatest Engineering achievement of the $20^{\text {th }}$ century to a weak stressed and vulnerable network. On the other hand, the Nigeria's electricity demand is rapidly increasing, leading to the power system facilities being operated near their capacity limits, it is assumed that the generating units may need to triple by 2020 to keep up with growing demand, requiring about 10,000 $\mathrm{MW}$ of new generating capacity. By projection Nigeria electricity demand in 2020 may grow at $1.8 \%$ per annum requiring over 40,000 MW of new generating capacity. Going by our estimate this capital project would require roughly about 10 new generating stations plus associated transmission and distribution facilities amounting to an investment of over $\$ 20$ billion (Ogbuefi,2015).

Technically, the limitation on power transfer capacity on a transmission line can always be removed by addition of new transmission capacity, but the economic, political and environmental considerations in building of new transmission facilities have made this option not always desirable. Therefore, there is every need to employ power electronic devices to be installed on the existing $330 \mathrm{kv}$ Nigerian power system for efficient power delivery.

Several methods which could be used to improve the performances of transmission lines according to Oleka, et al., (2016) include: Installation of New Transmission Line, Reconductoring, Transmission Line/Terminal Equipment Replacements, Voltage Upgrade, Conversion from single circuit to double circuit, Phase Shifting and Reactive Power Compensation.

Installation of transmission lines are usually the first option that comes to mind whenever a transmission line is limited in the amount of power it can transmit, so as to alleviate overloading by providing additional paths for power flow. It is beneficial by increasing the reliability of the transmission system. However, it has to pass through 
economic, political and environmental hurdles.

The term Flexible Alternating Current Transmission System (FACTS) devices describes a wide range of high voltage, large power electronic converters that can increase the flexibility of power systems to enhance AC system controllability, stability and increase power transfer capability (Sharma and Jagtap,2016).

FACTS devices stabilize transmission systems with increased transfer capability and reduced risk of line trips. Other benefits attributed to FACTS devices are additional energy sales due to increased transmission capability, reduced wheeling charges due to increased transmission capability and due to delay in investment of high voltage transmission lines or even new power generation facilities. These devices stabilize transmission systems with increased transfer capability and reduced risk of line trips (Kumar and Dubey, 2015). The major problem in power system is upholding steady acceptable system parameters like bus voltage, reactive power and active power under normal operating and anomalous conditions. This is usually system regulation problem and regaining synchronism after a major fault is critical for this phenomenon as Faults can cause loss of synchronism. As effects of instability, faults occur due to insulation breakdown or compromise as result of lightning ionizing air, power cables blowing together in the wind, animals or plants coming in contact with the wires, salt spray, pollution on insulators, system overloading, long transmission lines with uncontrolled buses at the receiving end, shortage of local reactive power, intrinsic factors, natural causes like harsh weather and small generation reserve margins. Such system disturbances have led to the introduction of FACTS devices such as Static Var Compensators (SVC), Static Synchronous Series Compensator (SSSC) Static Synchronous Compensator (STATCOM), Unified Power Controller (UPFC) and Interline Power flow Controller (IPFC), (Karthik and Arul, 2013) and (Makkar and Dewan, 2015). In stable power systems, when synchronous machines are disturbed, synchronism will either go back to their original state if there is no net change of power or will reach a new state without loss of synchronism and when there is net change in power; synchronism is lost (Satheesh and Manigandan, 2015). Due to FACTS devices, the power can be transmitted through the chosen routes with consideration to mitigate the loss thereby averting losses due to system tripping or outages. STATCOM, UPFC and SSSC, for instance, are very versatile FACTS controllers. The conventional approach often requires a precise mathematical model of the controlled systems. In power system practice and taking Nigeria as an example, there exist parameter uncertainty problems in the plant modeling and, also, since it is large, complex, geographically widely distributed, and can be affected by unexpected events, the conventional controllers often perform satisfactorily over a rather limited range of operation. These reasons also make global control very difficult.

\section{Materials and Method}

\subsection{Modeling of Power Systems with STATCOM}

It is acceptable to expect that for the aim of positive sequence power flow analysis the STATCOM will be represented by a synchronous voltage source with maximum and minimum voltage magnitude limits (Acha et al, 2004). The synchronous voltage source stands for the fundamental Fourier series component of the switched voltage waveform at the AC converter terminal of the STATCOM. The bus at which the STATCOM is connected is represented as a PV bus, which may change to a PQ bus in the case of limits being violated. In this case, the generated or absorbed reactive power would reach to the maximum limit. The STATCOM equivalent circuit shown in Figure 3.1 is used to obtain the mathematical model of the controller for incorporation in power flow algorithms (Adepoju and Komolafe, 2011). 

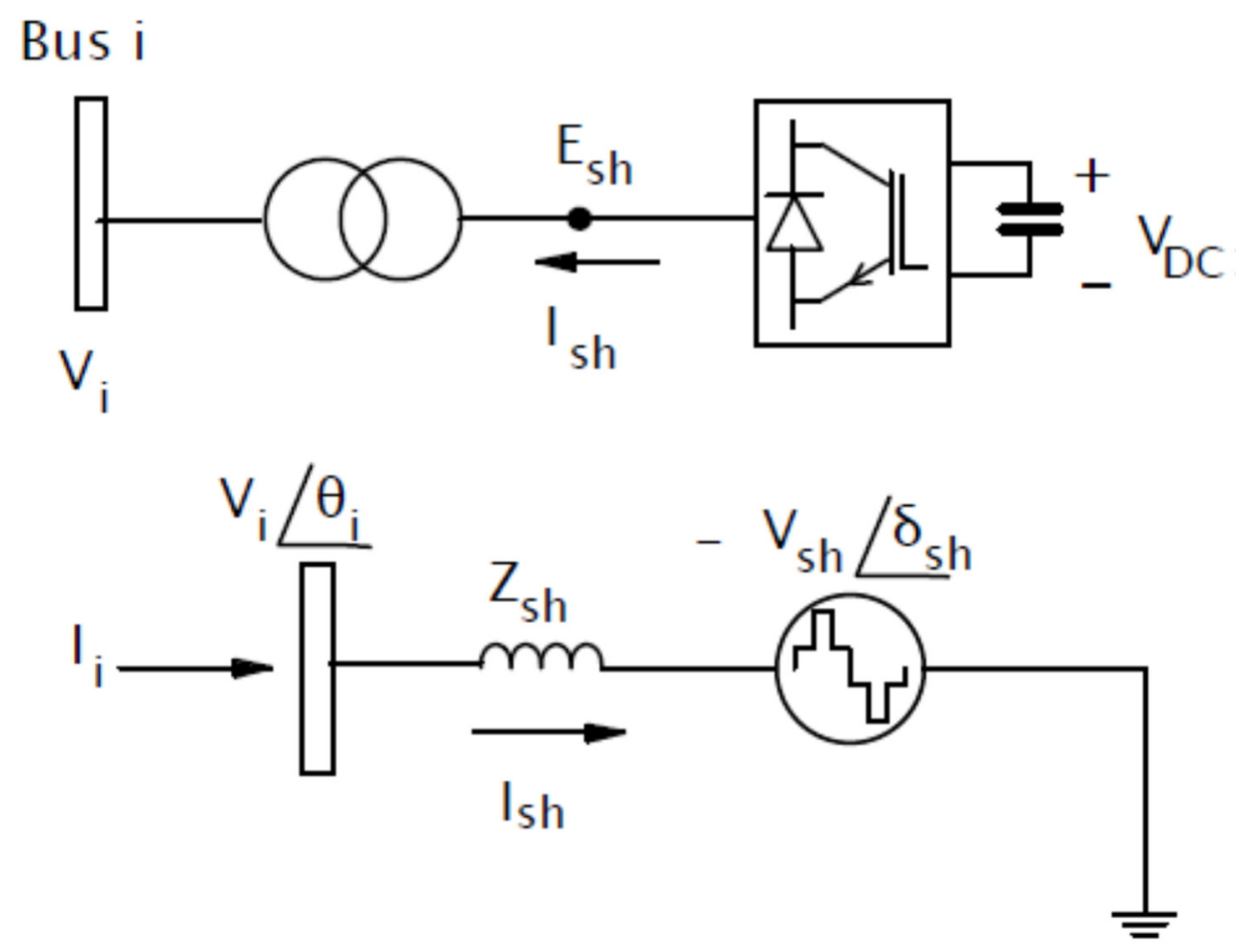

Figure 1: Thevenin's equivalent circuit diagram of STATCOM: (a) STATCOM schematic diagram; (b) STATCOM equivalent circuit

The power flow equations for the STATCOM are derived below:

From first principles and assuming the voltage source representation: (Aborisade et al, 2014):

$V_{\operatorname{sh}}=v_{\operatorname{sh}} \angle \delta_{\operatorname{sh}}$, also $V_{i}=v_{i} \angle \theta_{i}$,

$E_{\operatorname{sh}}=V_{\operatorname{sh}}\left(\cos \delta_{\operatorname{sh}}+j \sin \delta_{\operatorname{sh}}\right)$

From the STATCOM equivalent circuit of figure 1;

$S_{\operatorname{sh}}=V_{\operatorname{sh}} I_{s h}^{*}=V_{s h} Y_{s h}^{*}\left(V_{s h}^{*}-V_{i}^{*}\right)$

After performing some complex operations, the following active and reactive power equations are obtained for the converter and bus i, respectively:
$P_{s h}=V_{s h}^{2} G_{s h}+V_{s h} V_{i}\left[G_{s h} \cos \left(\delta_{s h}-\theta_{i}\right)+B_{s h} \sin \left(\delta_{s h}-\theta_{i}\right)\right]$
$Q_{s h}=V_{s h}^{2} B_{s h}+V_{s h} V_{i}\left[G_{s h} \sin \left(\delta_{s h}-\theta_{i}\right)-B_{s h} \cos \left(\delta_{s h}-\theta_{i}\right)\right]$
$P_{i}=V_{i}^{2} G_{s h}+V_{i} V_{s h}\left[G_{s h} \cos \left(\theta_{i}-\delta_{s h}\right)+B_{s h} \sin \left(\theta_{i}-\delta_{s h}\right)\right]$
$Q_{i}=V_{i}^{2} B_{s h}+V_{i} V_{s h}\left[G_{s h} \sin \left(\theta_{i}-\delta_{s h}\right)-B_{\operatorname{sh}} \cos \left(\theta_{i}-\delta_{\operatorname{sh}}\right)\right]$

Using these power equations, the linearized STATCOM model is as given in equation (8), where the voltage magnitude $V_{s h}$ and phase angle $\delta_{\text {घh }}$ are taken to be the state variables (Acha et al, 2000) $\left[\begin{array}{c}\Delta P_{i} \\ \Delta Q_{i} \\ \Delta P_{s h} \\ \Delta Q_{s h}\end{array}\right]=\left[\begin{array}{cccc}\frac{\partial P_{i}}{\partial \theta_{i}} & \frac{\partial P_{i}}{\partial V_{i}} V_{i} & \frac{\partial P_{i}}{\partial \delta_{s h}} & \frac{\partial P_{i}}{\partial V_{s h}} V_{s h} \\ \frac{\partial Q_{i}}{\partial \theta_{i}} & \frac{\partial Q_{i}}{\partial V_{i}} V_{i} & \frac{\partial Q_{i}}{\partial \delta_{s h}} & \frac{\partial Q_{i}}{\partial V_{s h}} V_{s h} \\ \frac{\partial P_{s h}}{\partial \theta_{i}} & \frac{\partial P_{s h}}{\partial V_{i}} V_{i} & \frac{\partial P_{s h}}{\partial \delta_{s h}} & \frac{\partial P_{s h}}{\partial V_{s h}} V_{s h} \\ \frac{\partial Q_{s h}}{\partial \theta_{i}} & \frac{\partial Q_{s h}}{\partial V_{i}} V_{i} & \frac{\partial Q_{s h}}{\partial \delta_{s h}} & \frac{\partial Q_{s h}}{\partial V_{s h}} V_{s h}\end{array}\right]\left[\begin{array}{c}\Delta \theta_{i} \\ \frac{\Delta V_{i}}{V_{i}} \\ \Delta \delta_{s h} \\ \Delta V_{s h} \\ V_{s h}\end{array}\right]$

\subsection{Development of Simulation Model and The Simulation Of 58 Bus Nigeria 330kV Transmission Network with STATCOM Device Connected}

The power flow model for STATCOM was derived and written in equation 8 and with this equation, the 58 bus Nigeria $330 \mathrm{kV}$ transmission line network was modeled in PSAT 2.1.8 and simulated in Matlab 2015b environment. The developed PSAT model is as shown in fig 2. The power flow solution of the Nigeria $330 \mathrm{kV}$ was implemented in the simulation using Newton - Raphson method of load flow solution. Egbin substation was chosen as the slack bus.

The voltage violated buses was sorted out from the result of the load flow analysis using the permissive 
voltage bus limit criteria of 0.95 to 1.05 pu or $₫ 5 \%$ of the rated bus voltage.

The search for the best position placement of STATCOM was done having known the positions of the violated buses. The method is just to insert the STATCOM device in any of these violated buses since STATCOM is a shunt device. The best position is based on the degree of performance enhancement spread.

\subsection{Simulation of Nigeria 330kV Transmission Line}

All simulations are done in MATLAB 2015b environment using specially design power system analysis tool PSAT 2.1.8. In this simulation tool, power flow of power system could be simulated and various results like bus voltage and phase angle, line flows and lines losses will be obtained. The simulation was done when no device is connected and when STATCOM device is connected to the $330 \mathrm{kV}$ network.

\subsection{Test case 1 (NO device connected in the test network)}

In this case no device was connected in the 58 bus Nigeria $330 \mathrm{kV}$ transmission line as shown in figure 2.

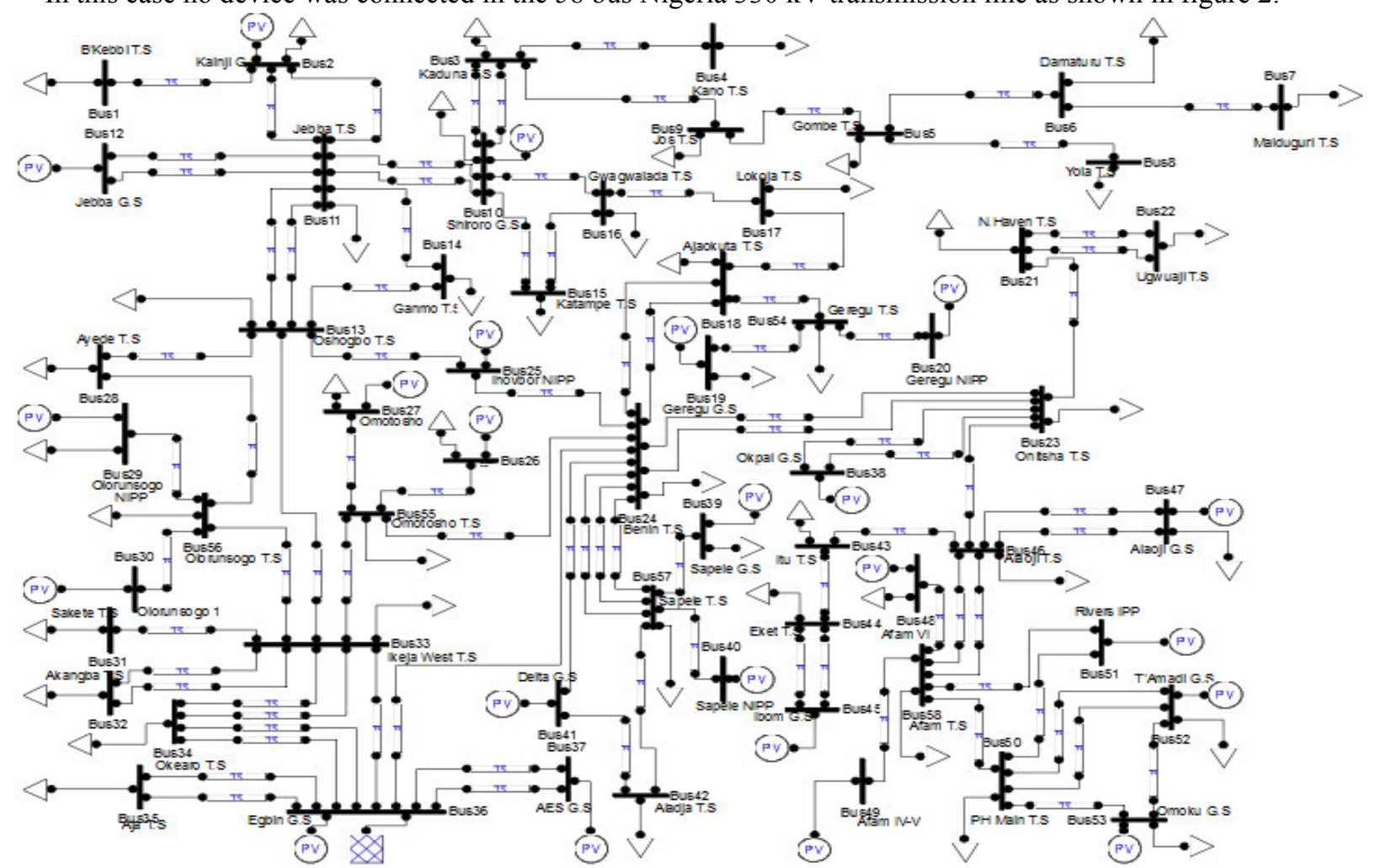

Figure 2: PSAT Model for 58 Bus Nigeria $330 \mathrm{kV}$ Network without FACT Device

\subsection{Test Case 2 (STATCOM Device Connected to The Test Network)}

In this test case, buses with voltage violations are connected with STATCOM one at a time and simulated to study the performance of the STATCOM in enhancing the voltage profile. PSAT model showing STATCOM connected to bus 7 is shown in Figure 3 . 


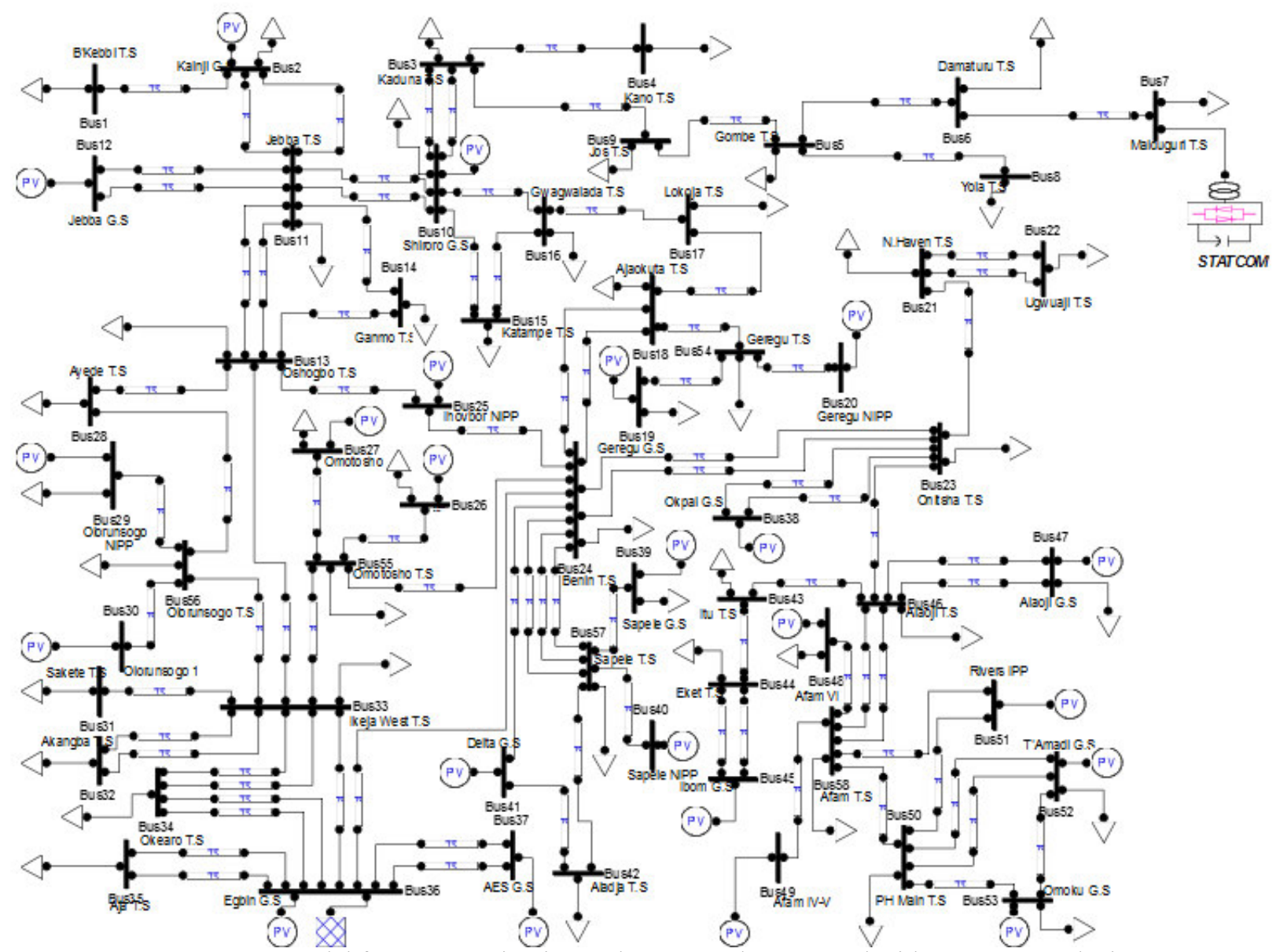

Figure 3: PSAT Model for 58 Bus Nigeria $330 \mathrm{kV}$ Network connected with STATCOM device

\subsection{Simulation conditions for STATCOM insertion}

STATCOM device was connected at bus 7 and simulations were done at various compensation conditions as stated below:

(i) conditions: power $=100 \mathrm{MW}$ and shunt current $I_{q}=0.7 \mathrm{pu}$

(ii) conditions: power $=100 \mathrm{MW}$ and shunt current $I_{q}=0.76 \mathrm{pu}$

Table 1: Network Statistics

\begin{tabular}{|c|c|c|}
\hline & \multicolumn{2}{|c|}{ NETWORK STATISTICS } \\
\hline Network condition & STATCOM & No FACTS \\
\hline Buses & 58 & 58 \\
\hline Lines & 87 & 87 \\
\hline Generators & 23 & 23 \\
\hline Loads & 46 & 46 \\
\hline
\end{tabular}

Table 2: Solution Statistics

\begin{tabular}{|c|c|c|}
\hline & \multicolumn{2}{|c|}{ SOLUTION STATISTICS } \\
\hline Power Flow Solution Type & \multicolumn{2}{|c|}{ Newton - Raphson } \\
\hline Simulation Condition & STATCOM & No FACT \\
\hline Number of Iterations: & 5 & 5 \\
\hline Maximum P mismatch [p.u.] & 41.22503 & $9.28 \mathrm{E}-12$ \\
\hline Maximum Q mismatch [p.u.] & 10.03604 & 0.197854 \\
\hline Power rate [MVA] & 100 & 100 \\
\hline
\end{tabular}




\section{Simulation Results and Discussion}

Table 3: Bus Voltages without FACTS Insertion

\begin{tabular}{|c|c|c|c|c|c|c|c|}
\hline $\begin{array}{c}\text { Bus } \\
\text { Number }\end{array}$ & Bus Name & $\begin{array}{c}\text { V } \\
\text { [p.u.] }\end{array}$ & $\begin{array}{c}\text { phase } \\
{[\mathrm{rad}]}\end{array}$ & $\begin{array}{l}\text { P gen } \\
\text { [p.u.] }\end{array}$ & $\begin{array}{l}\text { Q gen } \\
\text { [p.u.] }\end{array}$ & $\begin{array}{l}\text { P load } \\
\text { [p.u.] }\end{array}$ & $\begin{array}{l}\text { Q load } \\
\text { [p.u.] }\end{array}$ \\
\hline Bus 1 & BIRNIN KEBBI & 0.979671 & -0.67098 & $8.88 \mathrm{E}-16$ & $-6.7 \mathrm{E}-16$ & 1.62 & 1.22 \\
\hline Bus 2 & KAINJI & 0.97 & -0.50455 & 2.92 & -4.49602 & 0.89 & 0.67 \\
\hline Bus 3 & KADUNA & 0.989272 & -0.86088 & $-2 \mathrm{E}-12$ & $1.78 \mathrm{E}-13$ & 1.43 & 0.98 \\
\hline Bus 4 & KANO & 0.936896 & -1.00471 & $2.75 \mathrm{E}-13$ & $8.24 \mathrm{E}-14$ & 1.94 & 1.46 \\
\hline Bus 5 & GOMBE & 0.908595 & -1.14256 & $-2.5 \mathrm{E}-12$ & $4.15 \mathrm{E}-12$ & 0.68 & 0.51 \\
\hline Bus 6 & DAMATURU & 0.906397 & -1.17949 & $2.8 \mathrm{E}-12$ & $1.17 \mathrm{E}-12$ & 0.24 & 0.18 \\
\hline Bus 7 & MAIDUGURI & 0.897593 & -1.20893 & $7.61 \mathrm{E}-12$ & $5.93 \mathrm{E}-13$ & 0.31 & 0.2 \\
\hline Bus 8 & YOLA & 0.9012 & -1.16512 & $4.58 \mathrm{E}-12$ & $4.62 \mathrm{E}-13$ & 0.26 & 0.2 \\
\hline Bus 9 & JOS & 0.938719 & -1.00219 & $-9.3 \mathrm{E}-12$ & $2.22 \mathrm{E}-12$ & 0.72 & 0.54 \\
\hline Bus 10 & SHIRORO & 1 & -0.77658 & 3 & -2.26389 & 1.7 & 0.98 \\
\hline Bus 11 & JEBBA T/S & 1.0016 & -0.51444 & $-1.4 \mathrm{E}-13$ & $-1.2 \mathrm{E}-13$ & 2.6 & 1.95 \\
\hline Bus 12 & JEBBA G/S & 1 & -0.50967 & 4.03 & -2.04678 & 0 & 0 \\
\hline Bus 13 & OSHOGBO & 1.021973 & -0.4437 & $7.55 \mathrm{E}-15$ & $2.23 \mathrm{E}-14$ & 1.27 & 0.95 \\
\hline Bus 14 & GANMO & 1.013572 & -0.48713 & $2.18 \mathrm{E}-14$ & $9.44 \mathrm{E}-15$ & 1 & 0.75 \\
\hline Bus 15 & KATAMPE & 0.968761 & -0.8546 & $7.99 \mathrm{E}-15$ & $-8 \mathrm{E}-15$ & 3.03 & 2.27 \\
\hline Bus 16 & GWAGWALADA & 0.981015 & -0.81865 & 0 & $8.66 \mathrm{E}-15$ & 2.2 & 1.65 \\
\hline Bus 17 & LOKOJA & 0.983658 & -0.66839 & $-2.2 \mathrm{E}-16$ & $7.88 \mathrm{E}-15$ & 1.2 & 0.9 \\
\hline Bus 18 & AJAOKUTA & 0.985653 & -0.61087 & $-3.6 \mathrm{E}-13$ & $1.34 \mathrm{E}-13$ & 1.2 & 0.9 \\
\hline Bus 19 & GEREGU G/S & 0.985 & -0.60912 & 3.85 & 1.455111 & 2 & 1.5 \\
\hline Bus 20 & GEREGU (NIPP) & 0.985 & -0.60933 & 1.46 & -0.00394 & 0 & 0 \\
\hline Bus 21 & NEW HAVEN & 0.971998 & -0.93997 & $-4.9 \mathrm{E}-15$ & $-3.3 \mathrm{E}-14$ & 1.96 & 1.47 \\
\hline Bus 22 & UGWAJI & 0.971496 & -0.94174 & $8.08 \mathrm{E}-14$ & $2.33 \mathrm{E}-14$ & 1.75 & 1.31 \\
\hline Bus 23 & ONITSHA & 0.973807 & -0.82315 & $3.5 \mathrm{E}-14$ & $1.24 \mathrm{E}-13$ & 1 & 0.75 \\
\hline Bus 24 & BENIN & 0.995828 & -0.49639 & $2.98 \mathrm{E}-14$ & $-5.4 \mathrm{E}-14$ & 1.44 & 1.08 \\
\hline Bus 25 & IHOVBOR (NIPP) & 1 & -0.4835 & 1.166 & -1.38708 & 0 & 0 \\
\hline Bus 26 & OMOTOSHO (NIPP) & 1.006 & -0.33761 & 1.147 & 0.512867 & 0.9 & 0.44 \\
\hline Bus 27 & OMOTOSHO I & 1 & -0.33783 & 0.508 & -0.02731 & 0.3 & 0.14 \\
\hline Bus 28 & AYEDE & 0.980821 & -0.30971 & $-4.4 \mathrm{E}-15$ & $-2.9 \mathrm{E}-15$ & 1.74 & 1.31 \\
\hline Bus 29 & OLORUNSOGO (NIPP) & 0.973 & -0.19955 & 0.93 & -0.14974 & 0.71 & 0.58 \\
\hline Bus 30 & OLORUNSOGO I & 0.97 & -0.18351 & 1.027 & -0.97025 & 0 & 0 \\
\hline Bus 31 & SAKETE & 0.97798 & -0.12887 & $-4.4 \mathrm{E}-16$ & $9.77 \mathrm{E}-15$ & 2.05 & 1.1 \\
\hline Bus 32 & AKANGBA & 0.99619 & -0.09054 & $9.33 \mathrm{E}-15$ & $1.16 \mathrm{E}-13$ & 2.03 & 1.52 \\
\hline Bus 33 & IKEJA WEST & 0.999964 & -0.08613 & $2.13 \mathrm{E}-14$ & $-7.8 \mathrm{E}-14$ & 8.47 & 6.35 \\
\hline Bus 34 & OKEARO & 1.01469 & -0.04388 & $-6.7 \mathrm{E}-15$ & $3.72 \mathrm{E}-14$ & 1.2 & 0.9 \\
\hline Bus 35 & AJA & 1.031295 & -0.00213 & $-7.1 \mathrm{E}-15$ & $-5 \mathrm{E}-14$ & 1.15 & 0.86 \\
\hline Bus 36 & EGBIN & 1.033 & 0 & 41.23471 & 10.03976 & 0 & 0 \\
\hline Bus 37 & AES & 1 & 0.076642 & 2.452 & -3.49485 & 0 & 0 \\
\hline Bus 38 & OKPAI & 1 & -0.78611 & 4.66 & 1.692064 & 0 & 0 \\
\hline Bus 39 & SAPELE G/S & 0.985 & -0.48992 & 0.67 & -0.95668 & 0.4 & 0.18 \\
\hline Bus 40 & SAPELE (NIPP) & 1 & -0.48001 & 1.111 & -0.18175 & 0 & 0 \\
\hline Bus 41 & DELTA & 1.003 & -0.4791 & 3.41 & 0.905989 & 0 & 0 \\
\hline Bus 42 & ALADJA & 0.992198 & -0.49737 & $7.99 \mathrm{E}-15$ & $-1 \mathrm{E}-14$ & 2.1 & 1.58 \\
\hline Bus 43 & ITU & 0.97848 & -1.53205 & $3.55 \mathrm{E}-15$ & $-8.1 \mathrm{E}-15$ & 1.99 & 0.91 \\
\hline Bus 44 & EKET & 0.988548 & -1.56369 & $-1.1 \mathrm{E}-14$ & $-9.8 \mathrm{E}-15$ & 2 & 1.47 \\
\hline Bus 45 & IBOM & 1 & -1.56214 & 0.305 & 1.496835 & 0 & 0 \\
\hline Bus 46 & ALAOJI T/S & 0.981995 & -1.48959 & $1.33 \mathrm{E}-15$ & $6.13 \mathrm{E}-14$ & 2.4 & 1 \\
\hline Bus 47 & ALAOJI G/S & 1 & -1.49044 & 2.5 & 9.415142 & 2.27 & 1.7 \\
\hline Bus 48 & AFAM VI & 1 & -1.51254 & 6.46 & 8.916558 & 5.34 & 4.01 \\
\hline Bus 49 & AFAM IV-V & 0.956 & -1.51175 & 0.54 & -4.4108 & 0 & 0 \\
\hline Bus 50 & PH MAIN & 0.998574 & -1.53855 & $-8.9 \mathrm{E}-14$ & $5.84 \mathrm{E}-14$ & 2.8 & 1.4 \\
\hline Bus 51 & RIVERS (IPP) & 1 & -1.53337 & 0.8 & 1.498423 & 0 & 0 \\
\hline
\end{tabular}




\begin{tabular}{|c|c|c|c|c|c|c|c|}
\hline $\begin{array}{c}\text { Bus } \\
\text { Number }\end{array}$ & Bus Name & $\begin{array}{c}\mathrm{V} \\
{[\text { p.u.] }}\end{array}$ & $\begin{array}{c}\text { phase } \\
{[\mathrm{rad}]}\end{array}$ & $\begin{array}{c}\text { P gen } \\
{[\mathrm{p} . u .]}\end{array}$ & $\begin{array}{c}\text { Q gen } \\
{[\text { p.u.] }}\end{array}$ & $\begin{array}{c}\text { P load } \\
{[\text { p.u.] }}\end{array}$ & $\begin{array}{c}\text { Q load } \\
{[\text { p.u.] }}\end{array}$ \\
\hline Bus 52 & TRANS AMADI & 1 & -1.53852 & 1 & 1.70441 & 0.8 & 0.24 \\
\hline Bus 53 & OMOKU & 1 & -1.53867 & 0.448 & 0.208557 & 0.5 & 0.1 \\
\hline Bus 54 & GEREGU T/S & 0.984922 & -0.6101 & $8.33 \mathrm{E}-13$ & $1.02 \mathrm{E}-13$ & 2 & 1.5 \\
\hline Bus 55 & OMOTOSHO T/S & 0.992783 & -0.34213 & $-1.8 \mathrm{E}-15$ & $2.61 \mathrm{E}-14$ & 0.8 & 0.5 \\
\hline Bus 56 & OLORUNSOGO T/S & 0.980349 & -0.2047 & $-8.9 \mathrm{E}-15$ & $-2.7 \mathrm{E}-14$ & 0.71 & 0.58 \\
\hline Bus 57 & SAPELE T/S & 0.996462 & -0.4953 & $-5.9 \mathrm{E}-14$ & $-2.7 \mathrm{E}-14$ & 1 & 0.77 \\
\hline Bus 58 & AFAM T/S & 0.976824 & -1.51604 & $-6.2 \mathrm{E}-15$ & $1.47 \mathrm{E}-13$ & 7.2 & 4.12 \\
\hline
\end{tabular}

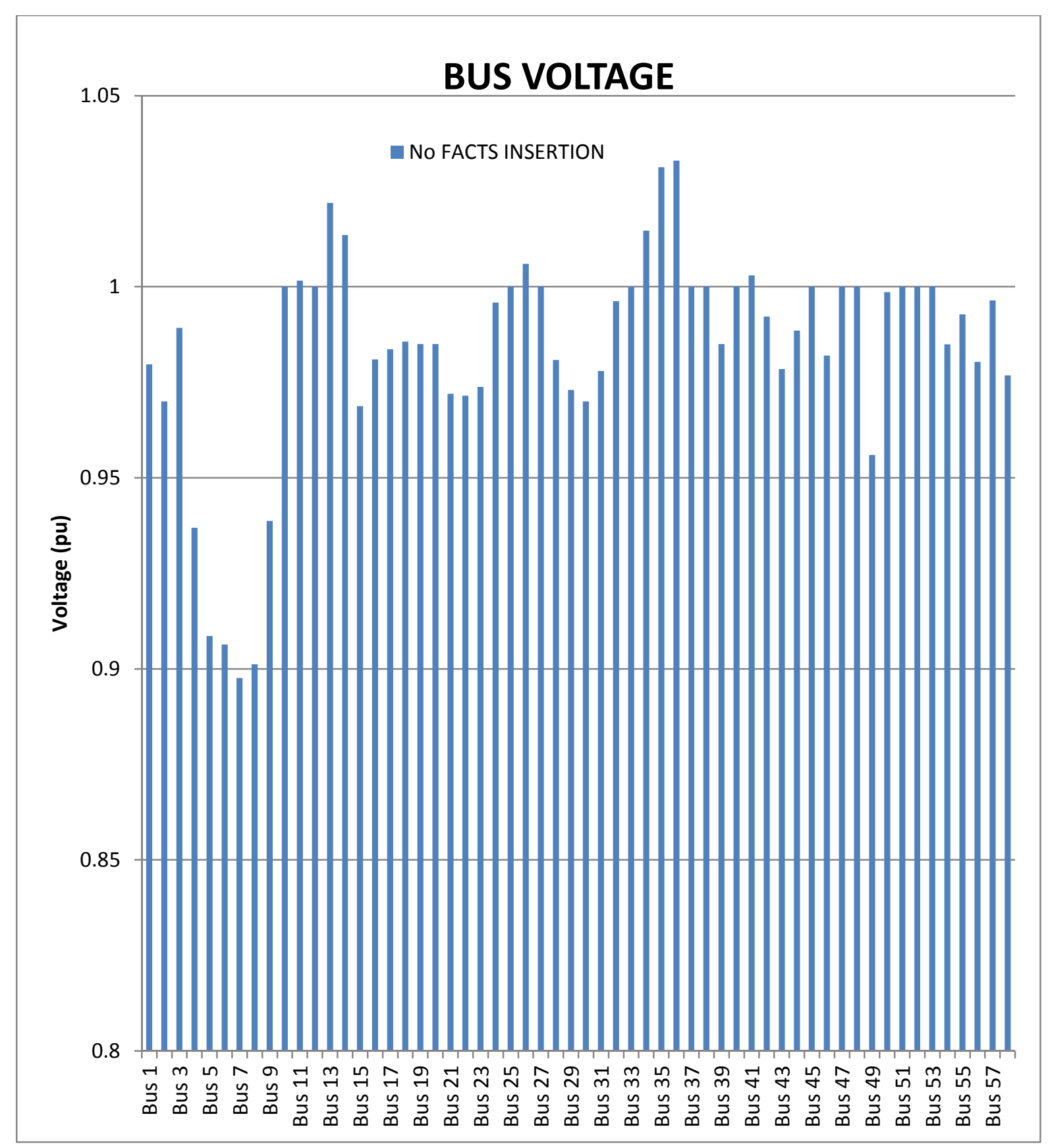

Figure 4: Bus voltages without FACTS insertion 
Table 4: Simulation Result of Violated Buses during Insertion of STATCOM at Various Buses

\begin{tabular}{|c|c|c|c|c|c|c|}
\hline \multicolumn{2}{|c|}{} & Bus 9 & Bus 5 & Bus 6 & Bus 7 & Bus 8 \\
\hline Bus Number & Bus Name & Voltage V[p.u.] & $\begin{array}{c}\text { Voltage } \\
\text { V[p.u.] }\end{array}$ & $\begin{array}{c}\text { Voltage } \\
\text { V[p.u.] }\end{array}$ & $\begin{array}{c}\text { Voltage } \\
\text { V[p.u.] }\end{array}$ & $\begin{array}{c}\text { Voltage } \\
\text { V[p.u.] }\end{array}$ \\
\hline 4 & Kano & 0.966401 & 0.957131 & 0.954405 & 0.952312 & 0.954758 \\
\hline 5 & Gombe & 1.043227 & 1.042307 & 1.024108 & 1.010146 & 1.026444 \\
\hline 6 & Damaturu & 1.049309 & 1.048337 & 1.04782 & 1.030606 & 1.031568 \\
\hline 7 & Maiduguri & 1.045633 & 1.04463 & 1.044097 & 1.048693 & 1.027308 \\
\hline 8 & Yola & 1.040173 & 1.039227 & 1.020483 & 1.006095 & 1.048368 \\
\hline 9 & Jos & 1.040302 & 1.008153 & 0.99874 & 0.991517 & 0.999953 \\
\hline
\end{tabular}

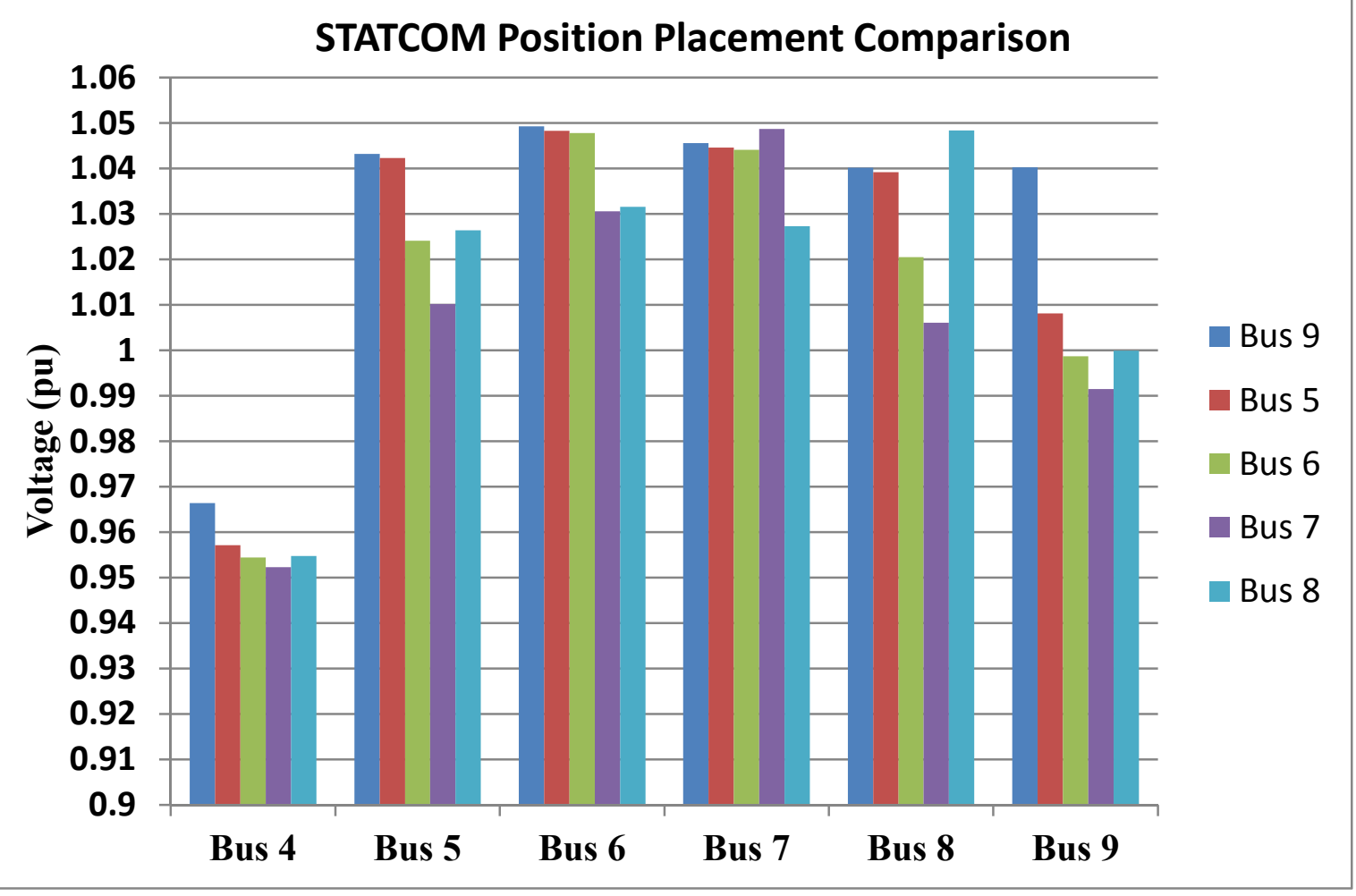

Figure 5 : STATCOM Position Placement Comparaisons (Bus Voltage improvement Perceptive)

Table 5: Violated Bus Voltage upon the Shunt Current Variation of the Inserted STATCOM

\begin{tabular}{|c|c|r|r|}
\hline \multicolumn{2}{|l|}{} & \multicolumn{1}{l|}{ Ish=0.7pu } & \multicolumn{1}{l|}{ Ish=0.76pu } \\
\hline Bus Number & Bus Name & Voltage V[p.u.] & Voltage V[p.u.] \\
\hline 4 & Kano & 0.964267 & 0.966401 \\
\hline 5 & Gombe & 1.033639 & 1.043227 \\
\hline 6 & Damaturu & 1.039175 & 1.049309 \\
\hline 7 & Maiduguri & 1.035168 & 1.045633 \\
\hline 8 & Yola & 1.0303 & 1.040173 \\
\hline 9 & Jos & 1.032875 & 1.040302 \\
\hline
\end{tabular}




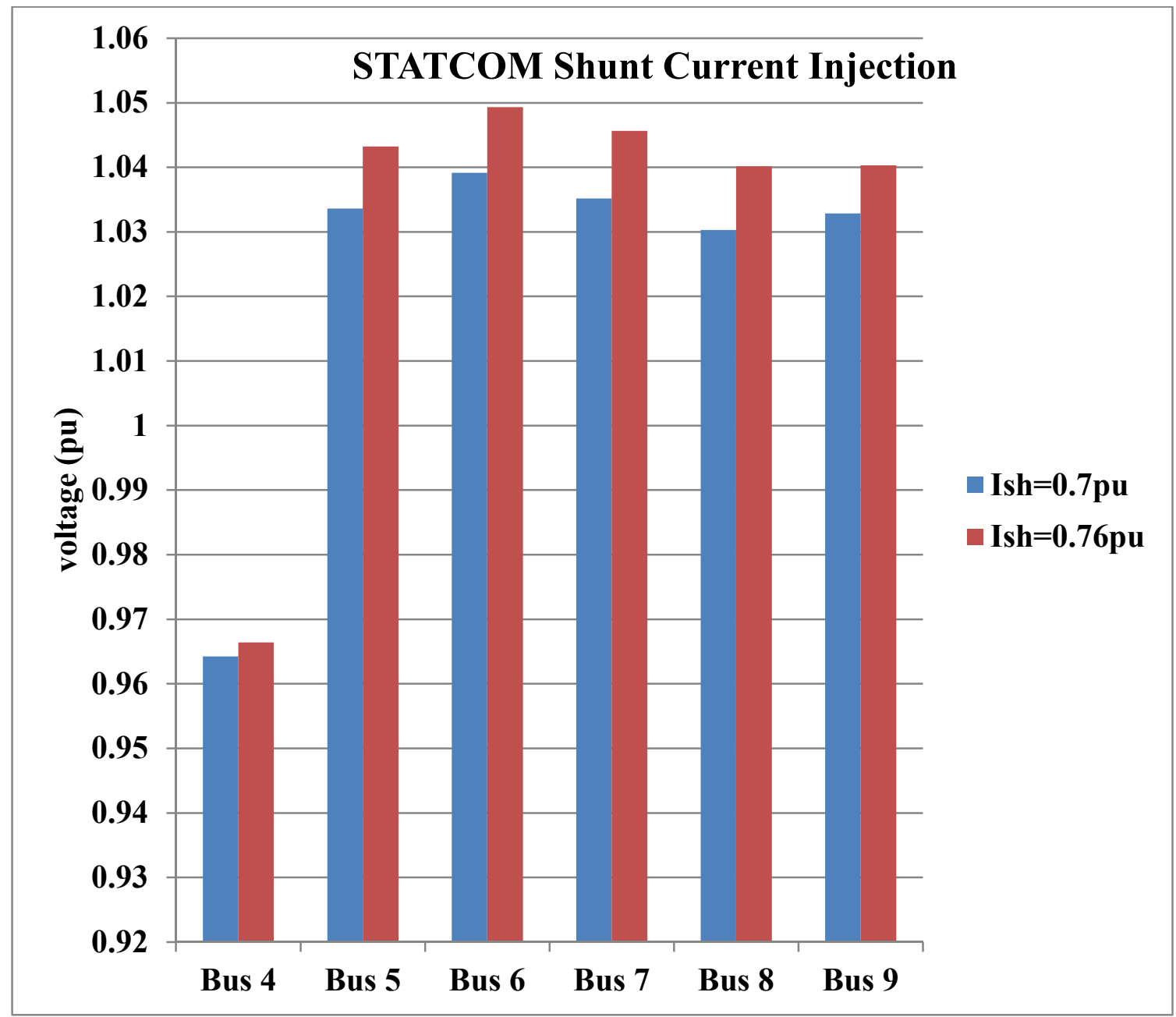

Figure 6: Violated Bus Voltage response upon the Shunt Current Variation of the Inserted STATCOM

The simulation of 58 buses, $330 \mathrm{kV}$ Nigerian transmission line network without compensation has shown that six (6) buses had voltage violation see table 5 and figure 4 and these buses are bus 4 (Kano), bus 5 (Gombe), bus 6 (Damaturu) bus 7 (Maiduguri), bus 8 (Yola) and bus 9 (Jos). These voltages violation had occurred majorly on the radial line serving Kaduna to Maiduguri with a single transmission line feeding all the violated busses from Kaduna substation. Violation in Kano was a case of high active and reactive power demand 1.94 pu and $1.46 \mathrm{pu}$ respectively. The major cause of this voltage violation in Kano substation was of course reactive power demand. The cause of violations on buses along Kaduna - Maiduguri line was mostly due to drops along the long line. The total power demand along this line from Kaduna - Maiduguri and the connected line from Gombe to Yola was $2.21 \mathrm{pu}$ and $1.63 \mathrm{pu}$, active and reactive power respectively. Maiduguri substation experienced the highest voltage violation because it had longest measured distance from Kaduna $795 \mathrm{~km}$ and power demand of $1.95+\mathrm{j} 1.43 \mathrm{pu}$. Compare with Kaduna to Yola, and which had second highest voltage violation of 0.9012 but had distance of 615 $\mathrm{km}$ from Kaduna and total power demand of $1.64+\mathrm{j} 1.23 \mathrm{pu}$

Discussion and Result analysis of STATCOM insertion.

The result of simulation of 58 buses, $330 \mathrm{kV}$ Nigerian transmission line network when inserted with STATCOM was recorded in table 4 and table 5 and shown graphically in figure 5 and figure 6 . The conditions for these simulations were enlisted in section 3.5. Positional placement assessment of STATCOM was recorded in table 4 and shown graphically in figure 5.

The simulation result of STATCOM showed that the position for the insertion of STATCOM for best performance enhancement was at bus 9 (Jos) see table 4 and figure 5. Table 4 showed that STATCOM when placed in bus 9 (Jos) had a better spread of performance enhancement than other positions. The condition of placement was given section 3.5 condition. The simulation conditions showed that at bus 7 (Maiduguri) the STATCOM required least shunt current to correct the voltage violated buses through with least performance enhancement spread. Observation of the result showed that the position where STATCOM had the highest bus voltage improvement was at that bus where STATCOM had the best of performance spread. Compare the 
performance spread at bus 9 (Jos) with that of bus 5 (Gombe), bus 6 (Damaturu), bus 7 (Maiduguri) and bus 8 (Yola) see table 4.

Increment in the shunt current of the STATCOM brought about increment in the shunt current of the performance enhancement see table 5 and fig 6. Simulation showed that when STATCOM was inserted at its best position bus 9 (Jos), that the value of bus voltage at bus 7 (Maiduguri) moved from 0.897593 pu to $1.035168 \mathrm{pu}$ and $1.045613 \mathrm{pu}$ for shunt current variation of $0.7 \mathrm{pu}$ and $0.76 \mathrm{pu}$ respectively.

\section{Conclusion}

The 58 buses, $330 \mathrm{kV}$ Nigerian transmission line network as shown by this paper has 7 voltage violated buses. These buses are Kano (0.9180 pu), Gombe (0.7890 pu), Damaturu (0.7634 pu), Maiduguri (0.7613 pu), Yola $(0.7769 \mathrm{pu})$ and Jos $(0.8756 \mathrm{pu})$. When these voltages violated buses where enhanced by the connection of STATCOM in Jos substation bus, the bus enhancement was $100 \%$ better than uncompensated Nigeria $330 \mathrm{kV}$ transmission network.

\section{References}

Ogbuefi U. C. and Madueme T. C. "A Power Flow Analysis of the Nigerian 330 KV Electric Power System" IOSR Journal of Electrical and Electronics Engineering (IOSR-JEEE) e-ISSN: 2278-1676, p-ISSN: 23203331, Volume 10, Issue 1 Ver. I (Jan - Feb. 2015), PP 46-57 www.iosrjournals.org DOI: 10.9790/167610114657

E.U. Oleka, S. N. Ndubisi \& G. K. Ijemaru "Electric Power Transmission Enhancement: A Case of Nigerian Electric Power Grid" American Journal of Electrical and Electronic Engineering, 2016, Vol. 4, No. 1, 33-39 DOI:10.12691/ajeee-4-1-5

Kumar and S. B. Dubey (2015), "Enhancement of Transient Stability in Transmission Line Using SVC Facts Controller", International Journal of Recent Technology and Engineering (IJRTE) ISSN: 2277-3878, Volume-2, Issue-2

M.Karthik and P.Arul, -Optimal Power Flow Control Using FACTS Devices,' International Journal of Emerging Science and Engineering (IJESE) ISSN: 2319-6378, Volume-1, Issue-12, October 2013

Makkar C.R and Dewan L. "Transient Stability Improvement of SMIB System using Line Impedance Compensation Mode of UPFC" Transactions on Engineering and Science Volume 3 Issue 12015

Satheesh, A. Maintaining Power System Stability with Facts Controller using Bees Algorithm and NN / A. Satheesh, T. Manigandan // Journal of Theoretical and Applied Information Technology. - 10th March 2015. - Vol. 49 Issue 1. - P. 38-47

Enrique Acha, Claudio R. FuerteEsquivel, Hugo Ambriz-Pérez and César AngelesCamacho Publisher: J.Wiley \& Sons. ISBN: 0-470-85271-2 Year of publication: 2004

E. Acha ,C. R. Fuerte-Esquivel, and H. Ambriz-Perez, "A comprehensive Newton-Raphson UPFC model for the quadratic power flow solution of practical power networks," in IEEE Transactions on Power Systems, vol. 15, no. 1, pp. 102-109, Feb. 2000, doi: 10.1109/59.852107.

Adepoju O.A., Komolafe G. A., Analysis and Modelling of Static Synchronous Compensator (STATCOM): A comparison of Power Injection and Current Injection Models in Power Flow Study International Journal of Advanced Science and Technology Vol. 36, November, 2011

Aborisade, D.O., Adebayo, I.G., and Oyesina, K.A. "A comparison of the Voltage Enhancement and Loss Reduction Capabilities of STATCOM and SSSC FACTS Controllers" American Journal of Engineering Research (AJER) e-ISSN : 2320-0847 p-ISSN : 2320-0936 Volume-03, Issue-01, pp-96-105 2014

Suraj Kumar and Priyajit Dash “A Study on TSCS, SSSC, SVC Facts Device” International Journal of Advanced Research in Electrical, Electronics and Instrumentation Engineering Vol. 5, Issue 6, June 2016 


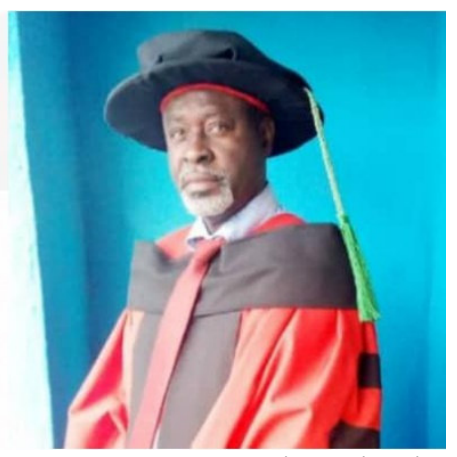

Dr. Ngang B.Ngang is a Nigerian,from the City of Ugep in Cross River State.He holds the following qualifications: Ph.D., Power Systems Engineering from Enugu State University of Science and Technology (ESUT),in 2019, a Master of Engineering (M.Eng.) and Bachelor of Engineering(B.Eng.) in Electrical and Electronic Engineering from University of Port Harcourt, Nigeria in 1996.He Obtained a Full Technological Certificate (FTC) from the City and Guilds of London Institute in 1986 and PG Diploma in Technical Education,1991. Dr Ngang equally had A Diploma in High Voltage Technology from Texas State Technical College (TSTC, Waco, Texas,USA, in 2004. This author became a member of Nigerian Society of Engineers (NSE) in 2001, a senior member of Nigerian Institution of Electrical and Electronic Engineers 2014, and a Fellow of Nigerian Society of Engineers in 2014.He is a registered Engineer with the Council for the Regulation of Engineering in Nigeria (COREN) in 2002, A former Chairman of Nigeria Society of Engineers, Eket Branch, Akwa Ibom State.

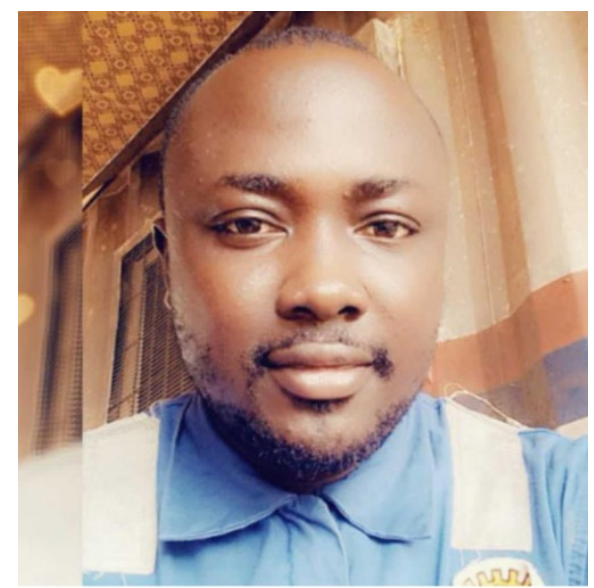

EZEKIEL NNAMERE ANEKE, MIEEE was born in May 14th in Enugu State, Nigeria. He received B.Eng degree in Electrical and Electronic Engineering from Enugu State University of Science and Technology in 2008; he also received his M.Eng degree (Electrical Power System and Machines) in Electrical and Electronic Engineering from same University in 2014. He is currently a Ph.D student in the Electrical and Electronics Engineering department of Enugu State University of Science and Technology(ESUT).

His research interests are in power system voltage stability and compensation of reactive powers in Transmission lines. He is a member of Nigerian Society of Engineers (MNSE) and a registered member of council for Registration of Engineering in Nigerian (COREN). 